This is an Open Access article distributed under the terms of the Creative Commons Attribution 4.0 International License which permits unrestricted non-commercial use, distribution, and reproduction in any medium, provided the original work is properly cited

\title{
FACTORS RELATED TO TREATMENT SEEKING BEHAVIOR AMONG SPONDYLITIS TUBERCULOSIS PATIENT: A SYSTEMATIC REVIEW
}

\section{Adelina Vidya Ardiyati ${ }^{*}$, Masfuri $^{2}$}

\section{Magister Student of Faculty of Nursing, Universitas Indonesia, Depok, Indonesia}

2. Departement of Medical Surgical Nursing, Faculty of Nursing, Universitas Indonesia, Depok, Indonesia

* Correspondence: adelina.vidya@ui.ac.id

\begin{abstract}
Tuberculosis is a global public health crisis. Spondylitis Tuberculos is secondary infection that caused by mycobacterium tuberculosis. Most of spondylitis TB patient comes to health care facilities with complication, such as deformity and deficit neurology. Health seeking behavior allows the patients to choose their preferres healthcare destination and the best timing of health seeking will resulting a good outcome of treatment. A systematic review was carried out to understand factors related to treatment seeking behavior including health seeking behavior, related to delays and attitude regarding spondylitis tuberculosis and the services linked with it. An electronical database search strategy was adopted using Proquest, EBSCOHost, and ScienceDirect to obtain research papers in the said subjects. Of 22 articles obtained by the end of this search process 10 full text articles were finally selected for the purpose of this review. Of the 10 studies identified, the results showed that some factors associated with related to treatment seeking behavior including (1) Perception of Disease and health service for Spondilitis TB; (2) Self healing and non medical treatment; (3) Knowledge and Misspperception of Spondilitis TB patient; (4) Reasons for seeking care/Delay in seeking care. Health seeking behavior and related delays are most importance in spondylitis TB care, because spondylitis TB requires timely treatment and protracted treatment to reach the best outcome of treatment. Required level of knowledge and positive health behavior helps the patient in taking timely help appropriate helath facility.
\end{abstract}

Keywords: Help seeking behavior, Patient delay, Treatment delay, Spondilitis TB 


\section{Introduction}

Tuberculosis spondylitis, also known as pott's disease, is an infectious disease caused by the bacterium Mycobacterium tuberculosis which affects the spinal region. In accordance with WHO Global Tuberculosis Report data in 2018, TB is one of ten causes of death caused by infectious agents. Globally, around 10 million people with TB disease in 2017 with a number of new TB cases of around 1 million people per year, and cause around 1.3 million deaths annually (1). Half of the incidence of extrapulmonary TB is TB in the spine or spinal region, and is the most common cause of neurological deficits after the incidence of injury or fracture, with a high degree of morbidity. Clinical manifestations that are chronic and non-specific and the complexity of the diagnostic test process that must be carried out in the diagnosis of spondylary TB causes many delays in the diagnosis and initial treatment of TB spondylitis patients. Research conducted by Batriel (2015) (2) stated that TB spondylitis patients coming to hospital had $69 \%$ of abscess complications, $40 \%$ reduction in neurological function, $16 \%$ deformity. The delay in making a diagnosis and starting treatment causes an increase in the possibility of complications experienced by the patient and the length of the treatment process, thus increasing the morbidity of TB spondylitis patients.

Not much research has been done on TB spondylitis patients related to factors that affect patients in seeking medical help to health services. Research focuses more on how to improve the health of TB spondylitis patients, regardless of how the patient experiences in seeking help from health workers to determine early diagnosis and start appropriate treatment. Based on this background, the reviewer was interested in conducting a systematic review of several research journals to find out more about the issues related to treatment seeking behavior in TB spondylitis patients.

\section{Objectives}

The purpose of this systematic review was to understand factors related to treatment seeking behavior among TB spondylitis patients. In addition, this systematic review helps in synthesizing empirical studies, so that they can identify: (1) Clinical, diagnostic, and management manifestations in TB spondylitis patients. (2) The incidence and causes of TB spondylitis patients are late in enforcing diagnostic and treatment. (3) Factors that influence a person in seeking medical help.

\section{Methods}

The process used to carry out this systematic review is that reviewers look for several research journal articles published through electronic databases. The electronic databases used are: Proquest, EBSCOHost, and ScienceDirect. The keyword used for English journals is "Tuberculosis Spondylitis" OR "Potts Disease" AND "Health Seeking Behavior". The search results in the query were found in 569 journals, EBSCOhost as many as 2,481 and ScienceDirect as many as 1,656 journals, so the total journal found was 3,250 . Then the journals found are specified based on inclusion criteria, namely: (1) Journals published in full text in English, (2) Journal articles published in the 2010-2018 period, (3) Types of quantitative research, (4) Journal articles has the main content of health care seeking behavior in TB spondylitis patients. After adjusting based on the inclusion criteria, the remaining journal articles were 355, of which 355 articles were selected based on the suitability of journal article titles with the aim of systematic reviews and by looking at the abstracts of each article so that the journal was 22,10 journal articles were selected will be analyzed. 
Chart 3.1 The process of systematic review (PRISMA Guideline)

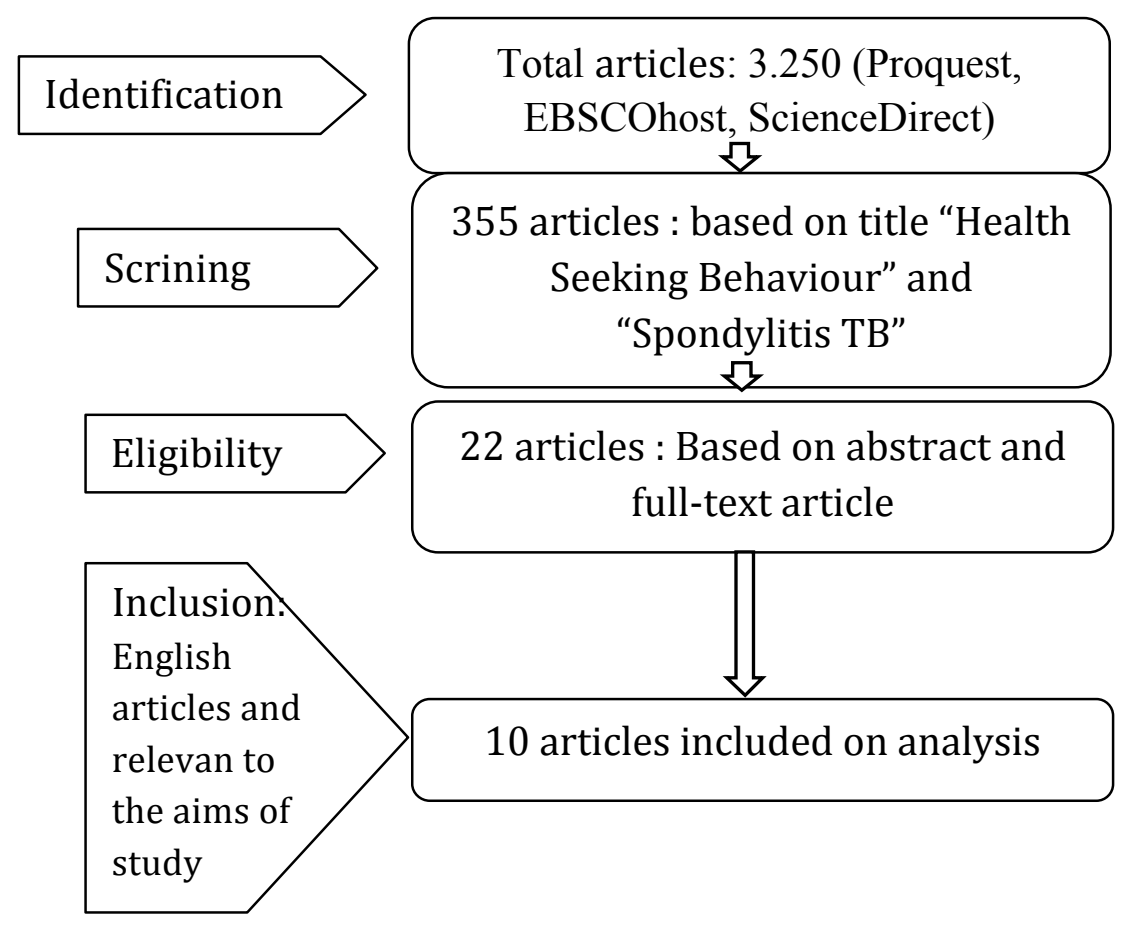

Of the 10 articles selected, research was conducted in several countries. All articles selected for this type of research are quantitative $(n=9)$ and qualitative approaches $(n=1)$. The most research design was cross sectional $(n=2)$, retrospective cohort $(n=3)$, prospective cohort $(n=3)$, qualitative $(n=3)$. The year of publication in all selected atricles is in the range 2010-2018. All samples in the study were patients with tuberculosis infection, with the most samples being 605 and the sample being at least 5 people in the qualitative study. 
Table of systematic literatur review result

\begin{tabular}{|c|c|c|c|c|c|c|c|}
\hline No & Author & Title & Purpose & Sample & $\begin{array}{c}\text { Methodolog } \\
\mathbf{y}\end{array}$ & Result & $\begin{array}{l}\text { Conclusion and } \\
\text { recomendation }\end{array}$ \\
\hline 1 & (2) & $\begin{array}{l}\text { The course of } \\
\text { spinal tuberculosis } \\
\text { (Pott disease): } \\
\text { results of the } \\
\text { multinational, } \\
\text { multicenter } \\
\text { Backbone-2 study }\end{array}$ & $\begin{array}{ll}\text { To find out } & \text { lab, } \\
\text { clinical, } & \text { liagnostic, and } \\
\text { management } & \\
\text { manifestations } \\
\text { ST }\end{array}$ & $\begin{array}{l}\text { Sample } 314 \\
\text { patients ST in } \\
\text { Turkey, Egypt, } \\
\text { Albania, } \\
\text { Greece. }\end{array}$ & $\begin{array}{l}\text { Consecutive } \\
\text { Retrospective } \\
\text { Using logistic } \\
\text { regression } \\
\text { statistical } \\
\text { analysis. }\end{array}$ & 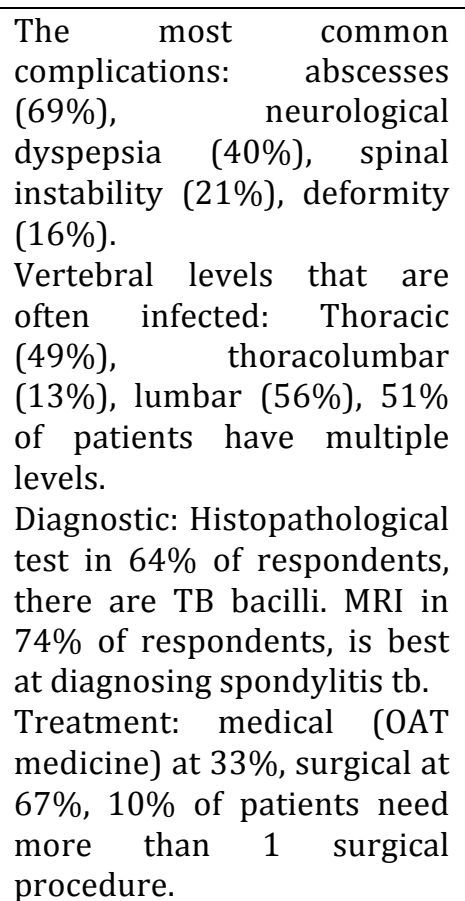 & $\begin{array}{l}\text { TB spondylitis produces } \\
\text { high morbidity, especially } \\
\text { in patients who are late in } \\
\text { diagnosis. Early etiologic } \\
\text { enforcement and early } \\
\text { diagnosis and appropriate } \\
\text { treatment are important to } \\
\text { prevent the development } \\
\text { of complications from the } \\
\text { disease. }\end{array}$ \\
\hline 2 & (13) & $\begin{array}{l}\text { Patients with } \\
\text { complicated Pott's } \\
\text { disease: } \\
\text { Management in a } \\
\text { rehabilitation } \\
\text { department and } \\
\text { functional } \\
\text { prognosis }\end{array}$ & $\begin{array}{l}\text { To find out } \\
\text { rehabilitation } \\
\text { management and } \\
\text { assess the } \\
\text { patient's ability } \\
\text { to do ADL }\end{array}$ & $\begin{array}{l}9 \text { potts disease } \\
\text { patients, from } \\
2000-2008 \text {, in } \\
\text { the } \\
\text { Department of } \\
\text { Physical } \\
\text { Medicine and } \\
\text { Functional } \\
\text { Rehabilitation, } \\
\text { Tunisia }\end{array}$ & $\begin{array}{l}\text { Retrospective } \\
\text { study }\end{array}$ & $\begin{array}{l}\text { All patients experienced } \\
\text { paraplegi and a bowel } \\
\text { bladder disorder, they took } \\
\text { anti-tuberculosis medication } \\
\text { for } 8 \text { months. Decompression } \\
\text { surgery was performed in } 6 \\
\text { patients, all patients received } \\
\text { a rehab program for an } \\
\text { average of } 47 \text { days, with a } \\
\text { physiotherapy program } \\
\text { twice a day. Measurement of } \\
\text { functional capabilities using }\end{array}$ & $\begin{array}{l}\text { Rehabilitation plays an } \\
\text { important role in the } \\
\text { surgical treatment of } \\
\text { patients with pott's } \\
\text { disease, to limit and } \\
\text { compensate for the } \\
\text { limitations of patients. }\end{array}$ \\
\hline
\end{tabular}




\begin{tabular}{|c|c|c|c|c|c|c|c|}
\hline & & & & & & MFI tools is $71 / 92$. & \\
\hline 3 & (14) & $\begin{array}{l}\text { Management in a } \\
\text { rehabilitation } \\
\text { department in } \\
\text { Pott's disease }\end{array}$ & $\begin{array}{l}\text { Assess the } \\
\text { contribution of } \\
\text { ST's patient } \\
\text { rehabilitation } \\
\text { program }\end{array}$ & $\begin{array}{l}29 \text { patients } \\
\text { eith ST who } \\
\text { take } \\
\text { rehabilitation } \\
\text { program }\end{array}$ & $\begin{array}{l}\text { Retrospective } \\
\text { study. The } \\
\text { study before } \\
\text { and after a } \\
\text { rehabilitation } \\
\text { program to see } \\
\text { the recovery of } \\
\text { muscle } \\
\text { strength, } \\
\text { disruption of } \\
\text { bowel and } \\
\text { bladder, } \\
\text { measured the } \\
\text { functional } \\
\text { independence } \\
\text { score. }\end{array}$ & $\begin{array}{l}\text { Location of } 5 \text { cases of } \\
\text { cervical infection, dorsal } 16, \\
\text { lumbar } 7,1 \text { patient in dorsal } \\
\text { and lumbar cervical. All } \\
\text { patients undergo anti-TB } \\
\text { treatment, decompression } \\
\text { surgery, and rehabilitation } \\
\text { programs. } 2 \text { quadriplegi } \\
\text { patients, } 3 \text { quadriparesis, } 14 \\
\text { complete paraplegi patients, } \\
\text { the rest were incomplete } \\
\text { paraplegi. } \\
\text { After } 32 \text { days with a 2-day } \\
\text { rehabilitation session, } 8 \\
\text { patients were still paraplegic } \\
\text { and incontinence bladder. } \\
\text { After } 2 \text { years the patient's } \\
\text { rehabilitation program has } \\
\text { increased functional ability. } \\
5 \text { patients with spinal } \\
\text { posture disorders. }\end{array}$ & $\begin{array}{l}\text { Delay Diagnosis of TB } \\
\text { spondylitis may occur due } \\
\text { to the absence of } \\
\text { neurological signs. MRI is } \\
\text { able to make an early } \\
\text { diagnosis. Rehabilitation is } \\
\text { an important component } \\
\text { to develop the quality of } \\
\text { life of patients. }\end{array}$ \\
\hline 4 & (15) & $\begin{array}{l}\text { Patients' Delay in } \\
\text { Seeking Health } \\
\text { Care for } \\
\text { Tuberculosis } \\
\text { Diagnosis in East } \\
\text { Gojjam Zone, } \\
\text { Northwest } \\
\text { Ethiopia }\end{array}$ & $\begin{array}{l}\text { To see the factors } \\
\text { that influence the } \\
\text { delay of patients } \\
\text { in seeking health } \\
\text { services to make } \\
\text { an early } \\
\text { diagnosis of TB }\end{array}$ & $\begin{array}{lr}\text { Using simple } \\
\text { random } \\
\text { sampling in } \\
605 \text { TB } \\
\text { patients } & \end{array}$ & $\begin{array}{l}\text { Cross Sectional } \\
\text { Study }\end{array}$ & $\begin{array}{l}\text { As many as } 53.4 \% \text { of } \mathrm{TB} \\
\text { patients were late in seeking } \\
\text { health services (median }=45 \\
\text { days; mean }=78 \text { days). } \\
\text { Criteria for patient delay: } \\
\text { Age } 45 \text { years, working as a } \\
\text { farmer, visiting traditional } \\
\text { medicine, self medication, } \\
\text { low knowledge about TB and } \\
\text { EPTB }\end{array}$ & $\begin{array}{l}\text { The delay in patients } \\
\text { seeking health services } \\
\text { was quite high at } 53.4 \% \text {. } \\
\text { Patients who get treatment } \\
\text { from holy water and } \\
\text { traditional medicine are } \\
\text { late in early diagnosis. }\end{array}$ \\
\hline 5 & (16) & $\begin{array}{l}\text { Musculoskeletal } \\
\text { manifestations of } \\
\text { tuberculosis: } \\
\text { An observational } \\
\text { study }\end{array}$ & $\begin{array}{l}\text { To find out } \\
\text { musculoskeletal } \\
\text { manifestations in } \\
\text { TB patients }\end{array}$ & $\begin{array}{lr}\text { Using } & 100 \\
\text { samples } & \text { of } \\
\text { active } & \text { TB } \\
\text { patients in } \\
\text { North Indian } \\
\text { TB Hospital }\end{array}$ & $\begin{array}{l}\text { Prospective } \\
\text { observational } \\
\text { study }\end{array}$ & $\begin{array}{l}\text { The age of the patient is in } \\
\text { the range of } 13 \text { to } 32 \text { years, } \\
\text { the ratio of Male: Female is } \\
43: 57 \text {. The average duration } \\
\text { of illness is } 6.85 \text { months. } \\
\text { Clinical manifestations in the } \\
\text { musculoskeletal area that }\end{array}$ & $\begin{array}{l}\text { Active TB patients have a } \\
\text { variety of rheumatological } \\
\text { manifestations. }\end{array}$ \\
\hline
\end{tabular}




\begin{tabular}{|c|c|c|c|c|c|c|c|}
\hline & & & & & & 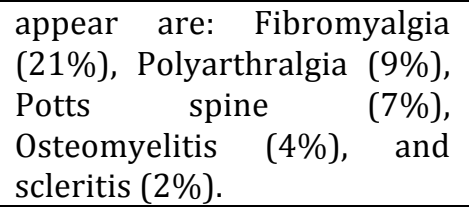 & \\
\hline 6 & (17) & $\begin{array}{l}\text { Outcome } \\
\text { assessment in } \\
\text { conservatively } \\
\text { managed patients } \\
\text { with cervical spine } \\
\text { tuberculosis }\end{array}$ & $\begin{array}{l}\text { To clinically } \\
\text { evaluate patients } \\
\text { and see a picture } \\
\text { of results from } \\
\text { conservative } \\
\text { management }\end{array}$ & $\begin{array}{l}42 \text { patients } \\
\text { with spinal } \\
\text { tuberculosis in } \\
\text { the spinal } \\
\text { region }\end{array}$ & $\begin{array}{l}\text { Prospective } \\
\text { study. The } \\
\text { patient was } \\
\text { given } \\
\text { antituberculosi } \\
\text { s treatment and } \\
\text { was followed } \\
\text { up in } 18 \\
\text { months. The } \\
\text { Modified } \\
\text { Barthel Index } \\
\text { (MBI) is used to } \\
\text { assess } \\
\text { patient's } \\
\text { disability. }\end{array}$ & $\begin{array}{l}\text { Of the } 38 \text { patients, } 29 \\
\text { patients had an MBI value of } \\
<12 \text { (poor outcome) at the } \\
\text { start of data collection, and } \\
18 \text { months after that } 81.6 \% \\
\text { of patients had an MBI } \\
\text { score }>12 \text {. Duration of the } \\
\text { disease was more than } 3 \\
\text { months, with clinical } \\
\text { manifestations decreased } \\
\text { motoric ability, bladder } \\
\text { disorders, spasm flexor, } \\
\text { compression of the spinal } \\
\text { cord and abscesses have a } \\
\text { significant relationship with } \\
\text { poor treatment results. }\end{array}$ & $\begin{array}{l}\text { Medical management is } \\
\text { effective management in } \\
\text { patients with spinal spinal } \\
\text { tuberculosis. Patients with } \\
\text { spinal cord compression } \\
\text { and abscesses in the spinal } \\
\text { area show poor } \\
\text { management results }\end{array}$ \\
\hline 7 & (18) & $\begin{array}{l}\text { Pulmonary } \\
\text { tuberculosis in } \\
\text { Patna, India: } \\
\text { Durations, delays, } \\
\text { and health } \\
\text { care seeking } \\
\text { behaviour among } \\
\text { patients identified } \\
\text { through household } \\
\text { surveys }\end{array}$ & $\begin{array}{l}\text { Determine the } \\
\text { delay that occurs } \\
\text { from the onset of } \\
\text { TB symptoms to } \\
\text { the initial } \\
\text { treatment in TB } \\
\text { patients in Patna, } \\
\text { India }\end{array}$ & $\begin{array}{l}109 \text { patients } \\
\text { identified as } \\
\text { having active } \\
\text { TB }\end{array}$ & $\begin{array}{l}\text { Cross Sectional } \\
\text { Study }\end{array}$ & $\begin{array}{l}\text { The average duration of } \\
\text { patients experiencing } \\
\text { symptoms is } 40 \text { days (1-164) } \\
\text { and TB patients retreatment } \\
\text { duration of symptoms for } 38 \\
\text { days. The total duration for } \\
\text { diagnosis is } 36 \% \text {, with older } \\
\text { age than young age, there is } \\
\text { no relationship between } \\
\text { gender, education, work, } \\
\text { type of symptoms with late } \\
\text { diagnosis and duration in } \\
\text { seeking health services. } \\
\text { The average duration of } \\
\text { seeking health services is } 15 \\
\text { days. }\end{array}$ & $\begin{array}{l}\text { Populations at risk of } \\
\text { developing TB need to be } \\
\text { regularly controlled to } \\
\text { minimize delays } \\
\text { diagnosing. }\end{array}$ \\
\hline 8 & (19) & $\begin{array}{l}\text { Perceptions of } \\
\text { tuberculosis and }\end{array}$ & $\begin{array}{l}\text { To explore } \\
\text { patients' }\end{array}$ & $\begin{array}{l}640 \\
\text { respondents in }\end{array}$ & $\begin{array}{l}\text { Qualitative } \\
\text { approach }\end{array}$ & $\begin{array}{l}60 \% \text { of respondents were } \\
\text { identified as having an }\end{array}$ & $\begin{array}{l}\text { Providing health education } \\
\text { must be given to increase }\end{array}$ \\
\hline
\end{tabular}

International Journal of Nursing and Health Services (IJNHS), Volume 2, Issue 2, 2019 | 95 


\begin{tabular}{|c|c|c|c|c|c|c|c|}
\hline & & $\begin{array}{l}\text { health seeking } \\
\text { behaviour } \\
\text { in rural Inner } \\
\text { Mongolia, China }\end{array}$ & $\begin{array}{l}\text { perceptions of } \\
\text { TB, the pattern of } \\
\text { seeking health } \\
\text { services in rural } \\
\text { communities in } \\
\text { Mongolia, China }\end{array}$ & $\begin{array}{l}\text { rural Mongolia } \\
\text { with a high } \\
\text { prevalence of } \\
\text { TB incidence. }\end{array}$ & $\begin{array}{l}\text { conducting FGD } \\
\text { on } 20 \text { groups } \\
\text { and } \\
\text { quantitative } \\
\text { approaches by } \\
\text { giving } \\
\text { questionnaires } \\
\text { to each } \\
\text { respondent }\end{array}$ & $\begin{array}{l}\text { extended cough as the main } \\
\text { symptom of TB, while only } \\
40 \% \text { of respondents } \\
\text { perceived that TB was } \\
\text { caused by interactions that } \\
\text { were too close to TB } \\
\text { patients. } 70 \% \text { of patients are } \\
\text { unable to take TB treatment } \\
\text { and must be indebted to get } \\
\text { treatment. Social stigma is } \\
\text { related to the incidence of TB } \\
\text { which can prevent TB } \\
\text { patients from carrying out } \\
\text { social interactions. The } \\
\text { patient's socio-economic } \\
\text { status is related to the } \\
\text { perceptions of respondents } \\
\text { on TB. Women, parents, } \\
\text { income and low education } \\
\text { are associated with } \\
\text { respondents' low knowledge } \\
\text { about TB. All respondents } \\
\text { (farmers) said that they } \\
\text { visited health services only if } \\
\text { they failed to handle } \\
\text { themselves. Financial and } \\
\text { structural barriers are } \\
\text { factors that make farmers } \\
\text { stop visits to health services }\end{array}$ & $\begin{array}{l}\text { knowledge } \\
\text { misperceptions in the } \\
\text { community about the } \\
\text { causes, transmission, and } \\
\text { knowledge that TB can be } \\
\text { cured perfectly to reduce } \\
\text { the stigma that develops in } \\
\text { the community. }\end{array}$ \\
\hline 9 & (20) & $\begin{array}{l}\text { Analysis of } \\
\text { Treatment and } \\
\text { Prognosis of } 863 \\
\text { Patients with } \\
\text { Spinal } \\
\text { Tuberculosis in } \\
\text { Guizhou Province }\end{array}$ & $\begin{array}{l}\text { To get an } \\
\text { overview of the } \\
\text { treatment and } \\
\text { prognosis of } \\
\text { spinal } \\
\text { tuberculosis } \\
\text { patients in the } \\
\text { ghoizou province }\end{array}$ & $\begin{array}{l}\text { A total of } 783 \\
\text { patients with } \\
\text { spinal } \\
\text { tuberculosis } \\
\text { were } \\
\text { registered at } \\
\text { the hospital } \\
\text { during } 2006 \text { to } \\
2017 .\end{array}$ & $\begin{array}{l}\text { Prospective } \\
\text { Study, by } \\
\text { following up on } \\
\text { all respondents } \\
\text { on average for } \\
20 \text { months. }\end{array}$ & $\begin{array}{l}145 \text { patients took } \\
\text { conservative therapy, } 638 \\
\text { patients had to get surgical } \\
\text { therapy. The surgical } \\
\text { procedure is in the form of } \\
\text { removal of the lesion, bone } \\
\text { graft fusion, and internal } \\
\text { fixation. Symptoms, physical } \\
\text { signs, blood tests, and an } \\
\text { overview of diagnostic tests }\end{array}$ & $\begin{array}{l}\text { Individual management } \\
\text { must be done to get good } \\
\text { self-efficacy in patients. } \\
\text { Standardized } \\
\text { (conservative, or } \\
\text { conservative surgery) } \\
\text { antituberculosis treatment } \\
\text { should be given to patients } \\
\text { with spinal tuberculosis }\end{array}$ \\
\hline
\end{tabular}




\begin{tabular}{|c|c|c|c|c|c|c|c|}
\hline & & & & & & $\begin{array}{l}\text { showed progress in } 143 \\
\text { patients. } 20 \text { patients showed } \\
\text { clinical symptoms that were } \\
\text { difficult to cure, and } 12 \\
\text { patients experienced } \\
\text { recurrent local tuberculosis. }\end{array}$ & \\
\hline 10 & (3) & $\begin{array}{l}\text { The Tale of } \\
\text { Seeking } \\
\text { Treatment: A } \\
\text { Qualitative Study } \\
\text { of Pulmonary } \\
\text { Tuberculosis } \\
\text { Patients }\end{array}$ & $\begin{array}{l}\text { Exploring factors } \\
\text { that influence } \\
\text { tuberculosis } \\
\text { patients in } \\
\text { seeking health } \\
\text { services }\end{array}$ & $\begin{array}{l}5 \mathrm{~TB} \text { patients } \\
\text { in Surabaya, } \\
\text { Indonesia }\end{array}$ & $\begin{array}{l}\text { Qualitative } \\
\text { explorative } \\
\text { design }\end{array}$ & $\begin{array}{l}\text { The results of this study } \\
\text { indicate that the five } \\
\text { participants delivered a } \\
\text { sequence that was almost the } \\
\text { same in seeking health } \\
\text { services, namely: feeling } \\
\text { symptoms, asking others } \\
\text { about perceived symptoms, } \\
\text { doing non-medical treatment } \\
\text { to reduce symptoms, } \\
\text { considering the opinions of } \\
\text { others to come to health } \\
\text { services, decided to carry out } \\
\text { the treatment process in } \\
\text { health services. }\end{array}$ & $\begin{array}{l}\text { Research results show the } \\
\text { same pattern of behavior } \\
\text { seeking treatment. } \\
\text { Primary service facilities } \\
\text { must be able to make } \\
\text { interventions that can } \\
\text { encourage patients to get } \\
\text { professional health } \\
\text { services and reduce } \\
\text { treatment delays }\end{array}$ \\
\hline
\end{tabular}




\section{Result}

\section{a. Demographics and clinical conditions}

The proportion of sex in TB spondylitis patients is more common in men than women. The age of patients is in the range of 18-51 years. Comorbiditis in patients includes the presence of diabetes mellitus, chronic renal failure, malignancy, immunosuppression undergoing antineoplastic and glucocorticoid chemotherapy, and other comorbidities such as hypertension, coronary artery disease, COPD, asthma and nephrolithiasis.

The average duration of the appearance of the initial symptoms until the time of diagnosis is 78 days (in the range of 2 days - 1095 days). The most common complications: abscesses (69\%), neurological dyspepsia (40\%), spinal instability (21\%), deformity (16\%). Vertebral levels that are often infected: Thoracic (49\%), thoracolumbar (13\%), lumbar (56\%), 51\% of patients have multiple levels. Diagnostic: Histopathological test in $64 \%$ of respondents, there are TB bacilli. MRI in $74 \%$ of respondents, is best at diagnosing spondylitis tb. Treatment: medical at 33\%, surgical at $67 \%, 10 \%$ of patients need more than 1 surgical procedure.

\section{b. Factors related to treatment seeking behavior}

Perceptions of symptoms that are felt based on research in 314 TB spondylitis patients conducted by Batriel (2015) (2), namely pain in the spine, especially in the upper part of the spine. Other symptoms reported are fever, fatigue, night sweats, loss of $\mathrm{BB}$, hepatomegaly and splenomegaly. Symptoms felt by patients do not interfere with daily activities, so patients do not immediately seek treatment help to health care facilities, this is evidenced by research conducted by Batriel (2015) (2) showing that the average duration of the patient feels the beginning of symptoms until a visit to the facility health service which is 78 days. There are several TB spondylitis patients who have a high level of awareness of symptoms that are felt and immediately seek medical help to health workers as evidenced by a fast duration (2 days) from the onset of symptoms to visits to professional health personnel.

Self healing and non-medical treatment. Based on qualitative research conducted by Fendi Suhariadi (2016) (3) in tuberculosis-infected patients in Surabaya Indonesia, patients who feel symptoms or conditions of an unhealthy body choose to cure themselves using traditional methods or medicines, such as scrapings that are believed to reduce symptoms which is felt after a person is finished scraped and rested, and they use traditional medicines such as herbs that are taken regularly which are believed to make the body healthy again. Some participants reported, if in some time the action did not produce results, then the participant would consult with the closest people (such as family, friends, coworkers, etc.) to ask for opinions and consideration for visiting health care facilities to look for medication help.

Lack of wrong knowledge and trust. The cause of patients infected with late TB to visit health facilities is due to a lack of knowledge about diseases and mistaken beliefs. Symptoms that appear are considered as a normal condition of someone if too tired, too late to eat, or commonly called colds. So that according to them do not require help from health workers, until the symptoms are felt to be increasingly severe and disrupt their daily activities.

Reasons for seeking care / Delay in see care. Research conducted by Fendy (2016) (3) in tuberculosis-infected patients suggests that the factor that motivates a 
person to come to a health care facility, namely: the existence of conditions that aggravate symptoms as described above (For example : diabetes mellitus, hypertension, chronic renal failure, COPD, etc.), advice or opinions from people closest to the patient to seek medical help in a health care facility. The family and the surrounding environment play an important role in increasing patient awareness of symptoms and determining the patient's decision to visit health care facilities. Gilian M Craig (2013) (4) mentions a person's obstacle in seeking medical help to health care facilities is because of the stigma or negative views of the surrounding environment regarding natural illness. Socio, economic and demographic conditions of a person can also be an obstacle in seeking medical help.

\section{Discussion}

TB Spondylitis patients are often unaware of the disease, this is because the clinical symptoms that appear are non-specific and are chronic in nature so that they often lead to late diagnosis and increased morbidity. The study conducted by Batriel (2015) (2) which states that TB spondylitis patients come to hospital have had abscess complications of $69 \%$, decreased neurological function by $40 \%$, deformity as much as $16 \%$. The delay in making a diagnosis and starting treatment causes an increase in the possibility of complications experienced by the patient and the length of the treatment process, thus increasing the morbidity of TB spondylitis patients.

Delays by patients start from the time the symptoms appear until the first visit to a health facility. Meanwhile, delays by health workers began from the period between the patient's first visit to the diagnosis of the patient as a case of TB spondylitis (5). Based on the literature review conducted by Anwar (2012) (6) regarding factors that influence a person's behavior in seeking treatment, namely sociocultural conditions and economic conditions, in the journal also mentioned that the phenomenon that often arises in the community is medication, this happens mostly in the community with less economic conditions, the reason for the price of treatment in health workers is more expensive, requires a long time to seek treatment, the presence of a doctor who is not 24 hours, patient confidence in his knowledge of treatment (6). Myths and misunderstandings that exist in the community also play an important role in making and shaping people's behavior in seeking treatment, cultural values, understanding of diseases, and fear of stigma that arises in the community is also one of the factors that determine treatment options (7). Another study conducted by Atchessi (2018) (8) concluded that the cause of TB patients seeking treatment too late is the lack of health care facilities, financial presence, and distance that must be taken to seek treatment (8). Other factors such as the level of education, employment, and access to health services also affect a person in seeking medical help to health services (9).

Much literature about health-seeking behavior is dominated by the theory of Health Believe Model, which was introduced in 1950. This model was developed to understand the reasons for a person's delay in diagnosing an illness early. In this model it is said that a person will seek treatment depending on his ability to be aware of the symptoms, their perception of the disease, perceptions of the effects of the disease, perceptions of disease severity, perceptions of treatment benefits from the use of health services, and perceptions of obstacles or obstacles that might be faced when looking for medical help, opinions from other people, family, friends, or health workers (12). Based on the theory of Health Believe 
the model of perceptions that arise in a person is influenced by age, gender, ethnicity, social class, economic conditions, experience about illness, and knowledge of the disease (11). The strongest factor behind health seeking behavior is the low awareness of the symptoms that arise, one's perception of the disease and its severity (12).

\section{Conclusion And Recommendation}

Treatment seeking behavior and its relationship to late diagnosis and treatment are important in cases of TB spondylitis because patients with TB infection need a fast and appropriate time to be diagnosed and get treatment immediately in an effort to prevent further complications of TB spondylitis and more treatment or action complex. It requires a high level of understanding and awareness of the perceived symptoms and a strong desire to immediately seek medical help from a professional health worker. Efforts need to be made to increase knowledge and change people's perceptions about the health of sick conditions by providing health education by professional health workers, also need to develop development interventions by the government and health service facilities to conduct early detection in TB spondylitis patients.

\section{Reference}

1. Zumla A, George A, Sharma V, Herbert RH, Oxley A, Oliver M. The WHO 2014 global tuberculosis report-further to go. The Lancet Global Health. 2015 Jan 1;3(1):e10-2.

2. Batirel A, Erdem H, Sengoz G, Pehlivanoglu F, Ramosaco E, Gülsün S, Tekin R, Mete B, Balkan İI, Sevgi DY, Giannitsioti E. The course of spinal tuberculosis (Pott disease): results of the multinational, multicentre Backbone-2 study. Clinical Microbiology and Infection. 2015 Nov 1; 21(11): 1008-e9.

3. Suhariadi F, Zein RA, Alfian IN, Hadi C. The tale of seeking treatment: a qualitative study of pulmonary tuberculosis patients. Psychology, Community \& Health. 2016 Dec 15; 5(3): 229-43.

4. Craig GM. 'Nation','migration'and tuberculosis. Social Theory \& Health. 2007 Aug 1; 5(3): 267-84.

5. Bianchini S, Esposito A, Principi N, Esposito S. Spondylodiscitis in paediatric patients: the importance of early diagnosis and prolonged therapy. International journal of environmental research and public health. 2018 Jun; 15(6): 1195.

6. Anwar M, Green J, Norris P. Health-seeking behaviour in Pakistan: A narrative review of the existing literature. Public Health. 2012 Jun 1; 126(6): 507-17.

7. Kusimo 0, Olukolade R, Hassan A, Okwuonye L, Osinowo K, Ogbuji Q, Osho A, Ladipo OA. Perceptions of community members on tuberculosis and its effect on healthseeking behavior in Nigeria. International Journal of Mycobacteriology. 2015 Mar 1; 4:61.

8. Atchessi N, Ridde V, Abimbola S, Zunzunegui MV. Factors associated with the healthcare-seeking behaviour of older people in Nigeria. Archives of gerontology and geriatrics. 2018 Nov 1; 79:1-7.

9. Grover M, Bhagat N, Sharma N, Dhuria M. Treatment pathways of extrapulmonary patients diagnosed at a tertiary care hospital in Delhi, India. Lung India: official organ of Indian Chest Society. 2014 Jan; 31(1):16. 
10. Craig GM, Joly LM, Zumla A. 'Complex'but coping: experience of symptoms of tuberculosis and health care seeking behaviours-a qualitative interview study of urban risk groups, London, UK. BMC Public Health. 2014 Dec; 14(1): 618.

11. Pushpalata, N., \& Chandrika, K. B. (2017). Health care seeking behaviour- A theoretical perspective, 790-792. Retrieved from

https://www.worldwidejournals.com/paripex/recent_issues_pdf/2017/January/Janu ary_2017_1485002966_99.pdf

12. Craig GM, Joly LM, Zumla A. 'Complex'but coping: experience of symptoms of tuberculosis and health care seeking behaviours-a qualitative interview study of urban risk groups, London, UK. BMC Public Health. 2014 Dec; 14(1): 618

13. Zaoui A, Kanoun S, Boughamoura H, Maitigue MB, Bouaziz MA, Khachnaoui F, Rejeb N. Patients with complicated Pott's disease: Management in a rehabilitation department and functional prognosis. Annals of physical and rehabilitation medicine. 2012 Apr 1;55(3):190-200.

14. Toulgui E, Jemni S, Frioui S, Lazreg N, Mtaouaa S, Khachnaoui F. Management in a rehabilitation department in Pott's disease. Annals of physical and rehabilitation medicine. 2016 Sep 1; 59:e96.

15. Asres M, Gedefaw M, Kahsay A, Weldu Y. Patients' delay in seeking health care for tuberculosis diagnosis in East Gojjam Zone, Northwest Ethiopia. The American journal of tropical medicine and hygiene. 2017 May 3; 96(5): 1071-5.

16. Gupta N, Bhatnagar AK. Musculoskeletal manifestations of tuberculosis: An observational study. Journal of family medicine and primary care. 2018 May;7(3):538.

17. Bhandari A, Garg RK, Malhotra HS, Verma R, Singh MK, Jain A, Sharma PK. Outcome assessment in conservatively managed patients with cervical spine tuberculosis. Spinal Cord. 2014 Jun; 52(6): 489.

18. Mistry N, Lobo E, Shah S, Rangan S, Dholakia Y. Pulmonary tuberculosis in Patna, India: Durations, delays, and health care seeking behaviour among patients identified through household surveys. Journal of epidemiology and global health. 2017 Dec $1 ; 7(4): 241-8$.

19. Zhang T, Liu X, Bromley H, Tang S. Perceptions of tuberculosis and health seeking behaviour in rural Inner Mongolia, China. Health Policy. 2007 May 1; 81(2-3): 155-65.

20. Cao G, Rao J, Cai Y, Wang C, Liao W, Chen T, Qin J, Yuan H, Wang P. Analysis of Treatment and Prognosis of 863 Patients with Spinal Tuberculosis in Guizhou Province. BioMed research international. 2018; 2018. 